\title{
A Systematic Bibliographical Review: Barriers and Facilitators for Access to Legal Abortion in Low and Middle Income Countries
}

\author{
Freddy Andrés Barrios Arroyave 1,2,3, Paula Andrea Moreno Gutiérrez ${ }^{3}$ \\ ${ }^{1}$ Sexual and Reproductive Health Universidad el Bosque Bogota, Colombia, Doctoral Student in Epidemiology and Biostatistics \\ CES University, Medellin, Colombia \\ ${ }^{2}$ Researcher of Epidemiology and Biostatistics Group CES University and GISCO (Health and Community Research Group), \\ Pereira, Colombia \\ ${ }^{3}$ Department of Community Health, Faculty of Medicine, Fundacion Universitaria Autonoma de las Americas, Pereira, Colombia \\ Email: barrios.freddy@uces.edu.co
}

How to cite this paper: Arroyave, F.A.B. and Gutiérrez, P.A.M. (2018) A Systematic Bibliographical Review: Barriers and Facilitators for Access to Legal Abortion in Low and Middle Income Countries. Open Journal of Preventive Medicine, 8, 147-168. https://doi.org/10.4236/ojpm.2018.85015

Received: January 28, 2018

Accepted: May 15, 2018

Published: May 18, 2018

Copyright $\odot 2018$ by authors and Scientific Research Publishing Inc. This work is licensed under the Creative Commons Attribution International License (CC BY 4.0).

http://creativecommons.org/licenses/by/4.0/

\begin{abstract}
Background: There is a complex interplay between women's preferences, abortion services availability and the context in which these are provided. Even in countries where it is legal, denial of abortion is common, especially in low and middle income countries, forcing women to look for the service elsewhere and bringing serious consequences to the health and wellbeing of many women and their families. This non-systematic review pretends to answer the question: Which are the barriers to and facilitators for the access to legal abortion services in low and middle income countries? Methods: A non-systematic bibliographical review. Inclusion criteria: all quantitative, qualitative and evidence synthesis studies performed in low and middle income countries according to the World Bank classification for 2015 and published in English, Spanish and Portuguese language, between 2005 and 2017. Exclusion criteria: articles evaluating the efficacy of interventions, addressing the knowledge about abortion procedures among health care students and personnel, as well as those that only included sex workers. Results: The database search yield 199 articles in MEDLINE. 24 in Scopus and 38 in Scielo. A total of 22 articles including 15 countries from Africa $(n=6)$, Asia $(n=5)$, Central and South America $(n=3)$ and Europe $(n=1)$. The legal status of abortion in each of these countries was studied and described. For the analysis of the information, three categories of deepening were established: Laws and policies, Service delivery and Women's abortion care-seeking behavior. Conclusion: the determinants of access to abortion in low and middle income countries are convoluted as multiple delays and barriers usually overlap. Similarly, stigmatization has a great impact across all the steps of abortion provision.
\end{abstract}


Multiple facilitators were proposed in the three aspects of abortion provision, but they need to be adjusted depending on the context of each country.

\section{Keywords}

Abortion, Legal, Reproductive Rights, Public Health, Abortion Applicants

\section{Introduction}

Worldwide, it is estimated that 2.4 million maternal deaths occurred between 2003 and 2009, of which 7.9\% were caused by abortion complications, almost all of them in low and middle income countries as result of unsafe procedures [1]. Maternal mortality and morbidity rates have significant declined after the legalization of abortion [2]. In countries like Nepal, where abortion decriminalization in 2002 was followed by an early decline of $40 \%$ in septic abortions and later by a reduction of $30 \%$ in overall serious complications of unsafe abortion such as serious infections, injury to the reproductive system and systemic complications [3].

There is a complex interplay among women's preferences, abortion services availability and the context in which these are provided [4]. Even in countries where it is legal, denial of abortion is common, especially in low and middle income countries, forcing women to look for the service elsewhere and bringing serious consequences to the health and wellbeing of many women and their families [5] [6] [7] [8] [9].

A recent systematic review of the barriers and facilitators to abortion services in high income countries found that opposition to abortion among health professionals, direct and indirect costs of the procedure, unavailability of the service in rural areas, lack of training and of the proper resources were important barriers for the access to the service. Harassment of providers was the only form of stigma found in studies from rural Canada. On the contrary, the existence of specialized clinics, medical abortion via telemedicine and access to medical methods of abortion were identified as facilitators [4].

This non-systematic review was aimed to collect the existent literature about the barriers to and facilitators for the access to abortion in low and middle income countries, as the conditions in these countries differ significantly from that of high income countries.

\section{Methods}

A search of peer-reviewed articles was conducted in the following databases: MEDLINE, Scopus (English and Portuguese language) and Scielo (Spanish language). The search strings used were: MeSH: (Abortions, Legal OR Legal Abortion OR Legal Abortions OR Abortion on Demand) AND (Availability of Health Services OR Health Services Availability OR Accessibility, Health Services OR Access to Health Care OR Accessibility of Health Services OR Health Services Geographic accessibility OR Program Accessibility OR Accessibility, Program) 
and DeCS: Solicitantes de Aborto OR Aborto Legal OR Aborto. The references of the articles found were used to retrieve more articles of interest.

Inclusion criteria: all quantitative, qualitative and evidence synthesis studies performed in low and middle income countries according to the World Bank classification for 2015 and published in English, Spanish and Portuguese language, between 2005 and 2017. An article was included if the country/region in which it was made had the following criteria for legal abortion (2013) [10]: on demand or including all of the following: to save women's life, to preserve a woman's physical health and to preserve a woman's mental health/wellbeing. The availability of abortion in certain socioeconomic grounds, in cases of rape/incest, and because of fetal impairment was considered as optional.

Exclusion criteria: articles evaluating the efficacy of interventions, addressing the knowledge about abortion procedures among health care students and personnel, as well as those that only included sex workers.

Data from the articles was collected and analyzed using thematic content analysis. The Framework for evaluating safe abortion programs by Benson (2005) was modified to create a Framework for determinants of the access to safe abortion programs.

Data Analysis: the results were grouped into 3 categories for analysis: laws and policies, service delivery and women's abortion care-seeking behavior (Figure 1) [11]. The current situation of abortion in Serbia was addressed separately as

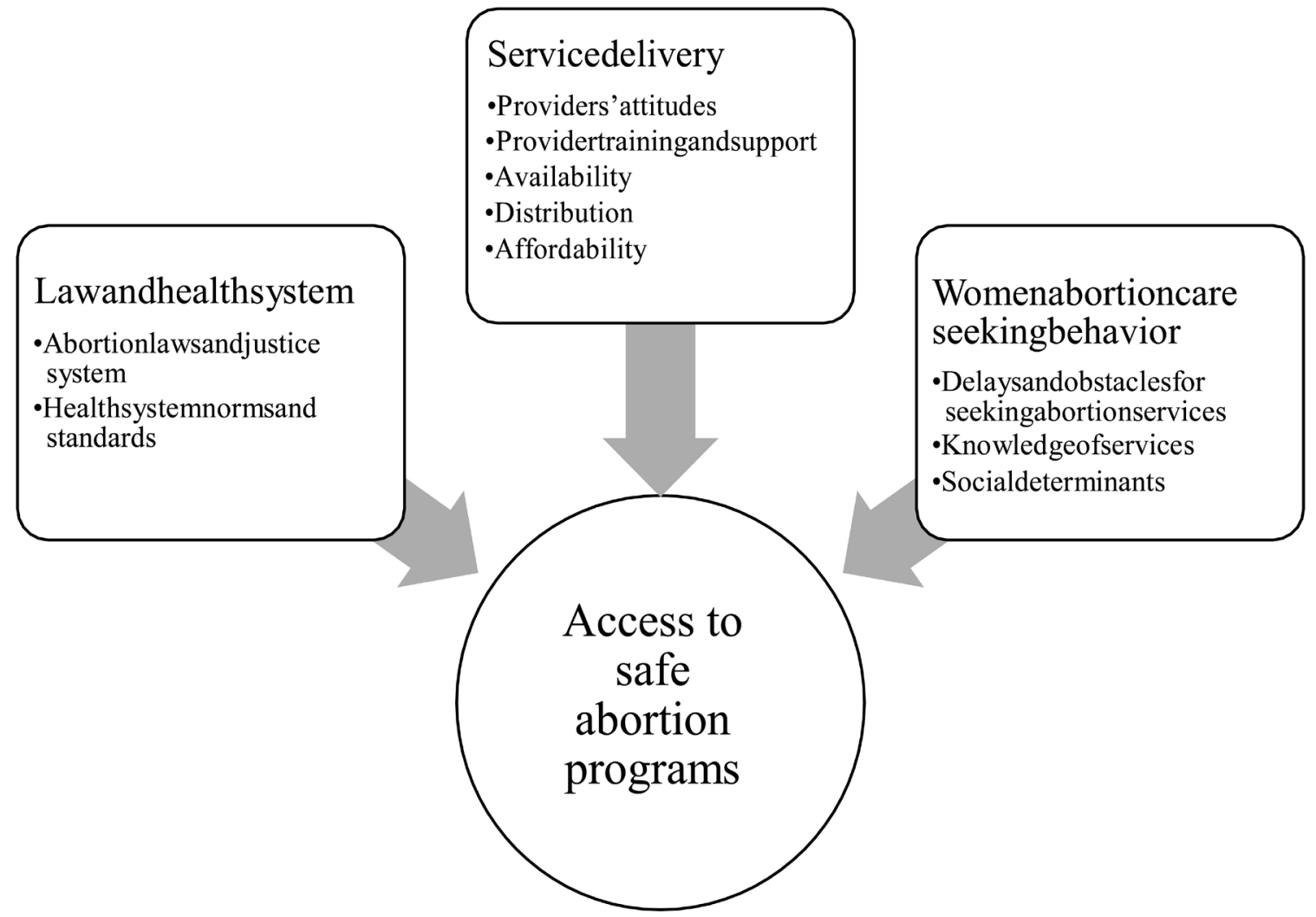

Adapted from the Framework for evaluating safe abortion programs by Benson (2005) [11].

Figure 1. Framework for determinants of the access to safe abortion programs. 
the conditions seemed to be very different from the other countries included. For each of the articles, the abstract was first reviewed to check that it met the criteria established in the search and to verify that its aim was in accordance with the search strategy. Subsequently, the methodology, the main results and the discussion of each study were analyzed and condensed in a matrix of Excel software which served as a tool to summarize the main contributions of each investigation. The possible biases of each study were considered and it was verified that the mention of some control strategies was written in each article.

\section{Results}

A flow diagram reflecting the article screening process can be seen at Figure 2. The database search yield 199 articles in MEDLINE. 24 in Scopus and 38 in Scielo. A total of 22 articles including 15 countries from Africa $(n=6)$, Asia $(n=$ 5), Central and South America $(n=3)$ and Europe $(n=1)$ (see Table 1). The legal status of abortion in each of these countries is shown in Table 2. Ten studies used a qualitative methodology, eight used quantitative methods, two mixed qualitative and quantitative methods and one was a review of the previous evidence (both legal and academic) about abortion in Serbia.

\subsection{Laws and Policies}

\subsubsection{Abortion Laws and Justice System}

Perceptions about the abortion law varied among the general population of Trinidad and Tobago, where $71 \%$ of the surveyed were in favor of the decriminalization of the current law in different degrees, while $29 \%$ favored a more restrictive law.

\section{Search Strategy.}

MeSH: (Abortions, Legal OR Legal Abortion OR Legal Abortions OR Abortion on Demand) AND (Availability of Health Services OR Health Services Availability OR Accessibility, Health Services OR Access to Health Care OR Accessibility of Health Services OR Health Services Geographic accessibility OR Program Accessibility OR Accessibility, Program

DeCS: Solicitantes de Aborto OR Aborto Legal OR Aborto

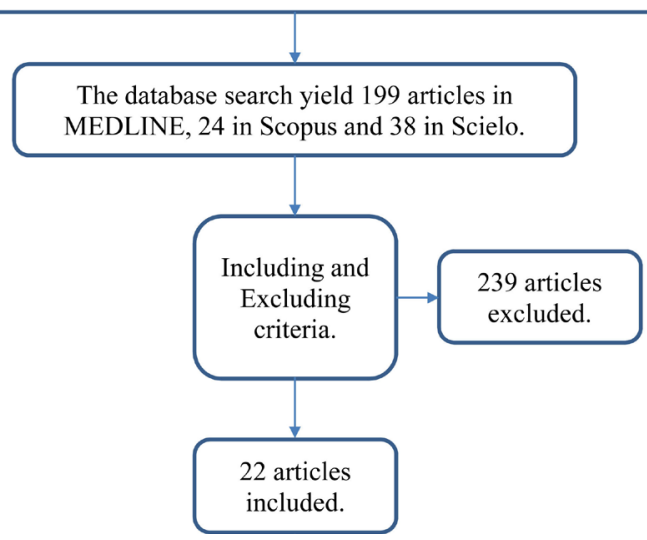

Figure 2. Flow diagram reflecting the article screening process. 
Table 1. Characteristics of the studies included in the review.

\begin{tabular}{|c|c|c|c|c|c|}
\hline Reference. & Country. & Focus of study. & Type of study. & Sample. & Population. \\
\hline \multicolumn{6}{|c|}{ Qualitative. } \\
\hline $\begin{array}{l}\text { Smith SS. The Challenges Procuring of Safe } \\
\text { Abortion Care in Botswana. African journal of } \\
\text { reproductive health. 2013; 17(4). }\end{array}$ & Botswana. & $\begin{array}{l}\text { Factors that make } \\
\text { terminating an unwanted } \\
\text { pregnancy difficult. }\end{array}$ & $\begin{array}{l}\text { Semi } \\
\text { structured } \\
\text { interviews. }\end{array}$ & $\mathrm{n}=21$ & $\begin{array}{l}\text { Women and } 4 \text { men from } \\
\text { the community, } 1 \text { human } \\
\text { rights lawyer and } 1 \\
\text { gynecologist. }\end{array}$ \\
\hline $\begin{array}{l}\text { Ouédraogo R, Sundby J. Social determinants } \\
\text { and access to induced abortion in Burkina } \\
\text { Faso: from two case studies. Obstetrics and } \\
\text { gynecology international. 2014; } 2014 \text {. }\end{array}$ & Burkina Faso. & $\begin{array}{l}\text { Social determinants of the } \\
\text { type of clandestine abortion } \\
\text { women are likely to access } \\
\text { and the time taken to } \\
\text { effective abortion. }\end{array}$ & $\begin{array}{l}\text { Review of } \\
\text { cases from } \\
\text { in-depth } \\
\text { interviews. }\end{array}$ & $\mathrm{n}=2$ & $\begin{array}{l}\text { Women in post-abortion } \\
\text { care. }\end{array}$ \\
\hline $\begin{array}{l}\text { Hung SL. Access to safe and legal abortion for } \\
\text { teenage women from deprived backgrounds in } \\
\text { Hong Kong. Reprod Health Matter. 2010; } \\
\text { 18(36): 102-10. }\end{array}$ & $\begin{array}{l}\text { Hong Kong, } \\
\text { China }^{*}\end{array}$ & $\begin{array}{l}\text { Experience of teenage } \\
\text { women from deprived } \\
\text { backgrounds who looks for } \\
\text { an abortion. }\end{array}$ & $\begin{array}{l}\text { In depth } \\
\text { interviews and } \\
\text { focus groups. }\end{array}$ & $\mathrm{n}=29$ & $\begin{array}{l}\text { Young women from } \\
\text { deprived backgrounds } \\
\text { seeking abortion. }\end{array}$ \\
\hline $\begin{array}{l}\text { Schwandt HM, Creanga } \\
\text { AA, Adanu RM, Danso KA, Agbenyega T, } \\
\text { Hindin MJ. Pathways to unsafe abortion in } \\
\text { Ghana: the role of male partners, women and } \\
\text { health care providers. Contraception. } \\
\text { 2013; 88(4): 509-17. }\end{array}$ & Ghana. & $\begin{array}{l}\text { Pathways to unsafe } \\
\text { abortion and the role male } \\
\text { partners and health care } \\
\text { providers. }\end{array}$ & $\begin{array}{l}\text { In-depth } \\
\text { interviews and } \\
3 \text { focus } \\
\text { groups. }\end{array}$ & $\mathrm{n}=58$ & $\begin{array}{l}\text { Female post-abortion } \\
\text { patients with complications } \\
\text { of unsafe abortion, male } \\
\text { partners, family planning } \\
\text { nurses and } \\
\text { obstetricians/gynecologists. }\end{array}$ \\
\hline $\begin{array}{l}\text { Aniteye P, Mayhew SH. Shaping legal abortion } \\
\text { provision in Ghana: using policy theory to } \\
\text { understand provider-related obstacles to policy }\end{array}$ & Ghana. & $\begin{array}{l}\text { Reasons for poor } \\
\text { implementation of the } \\
\text { abortion policy. }\end{array}$ & $\begin{array}{l}\text { In depth } \\
\text { Interviews. }\end{array}$ & $\mathrm{n}=76$ & $\begin{array}{l}\text { Health professionals } \\
\text { (Ob/gyn, midwives, } \\
\text { pharmacists and other) }\end{array}$ \\
\hline
\end{tabular}

implementation. Health Research Policy and

Systems. 2013; 11(1):23.

Potdar P, Barua A, Dalvie S, Pawar A. "If a India. woman has even one daughter, I refuse to perform the abortion": Sex determination and safe abortion in India. Reprod Health Matter. 2015; 23(45): 114-25.

Tong WT, Low WY, Wong YL, Choong SP, Malaysia. Jegasothy R. Exploring pregnancy termination experiences and needs among Malaysian women: A qualitative study. BMC public health. 2012; 12(1): 743.

Puri M, Lamichhane P, Harken T, Blum M, Nepal. Harper CC, Darney PD, et al. "Sometimes they used to whisper in our ears": health care workers' perceptions of the effects of abortion legalization in Nepal. BMC public health. 2012; 12(1): 297.

Harries J, Stinson K, Orner P. Health care providers' attitudes towards termination of pregnancy: A qualitative study in South Africa. BMC public health. 2009; 9(1): 296.

Gallo MF, Nghia NC. Real life is different: a Vietnam. qualitative study of why women delay abortion until the second trimester in Vietnam. Soc Sci Med. 2007; 64(9): 1812-22.
South Africa

Knowledge, attitudes and opinions of health service providers.

Health care workers' views of abortion legalization.

In depth interviews. structured interviews.

$$
\mathrm{n}=19 \text { Gynecologists. }
$$

interviews.

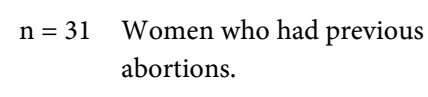

$\mathrm{n}=31 \quad$ Women who had previous

Determinants of delaying Semi obtaining abortion until the structured second trimester. interviews.

$$
\begin{array}{ll}
\text { In depth } \quad \mathrm{n}=34 & \begin{array}{l}
\text { Health care workers } \\
\text { related to abortion }
\end{array} \\
\text { interviews and } \\
\text { focus groups. }
\end{array} \quad \begin{aligned}
& \text { provision. }
\end{aligned}
$$




\section{Continued}

\section{Quantitative.}

Amado ED, García MCC, Cristancho KR, Salas Colombia.

EP, Hauzeur EB. Obstacles and challenges

following the partial decriminalisation of

abortion in Colombia. Reprod Health Matter.

2010; 18(36): 118-26.

Banerjee SK, Andersen KL, Buchanan RM, Warvadekar J. Woman-centered research on access to safe abortion services and implications for behavioral change communication interventions: a cross-sectional study of women in Bihar and Jharkhand, India. BMC public health. 2012; 12(1): 175 .

Gerdts C, DePiñeres T, Hajri S, Harries J, Hossain A, Puri M, et al. Denial of abortion in Nepal; Cape legal settings. J Fam Plan Reprod H. 2014: jfprhc-2014-100999.

India. Town, South
Barriers in looking for a legal termination of pregnancy.

Accessibility of safe
abortion services from the perspective of rural Indian women.
Case series. $\quad n=46 \quad$ Woman looking for abortion.
Clyde J, Bain J, Castagnaro K, Rueda M, Tatum Mexico city, C, Watson K. Evolving capacity and decision- Mexico* making in practice: adolescents' access to legal abortion services in Mexico City. Reprod Health Matter. 2013; 21(41): 167-75.

Adinma E, Adinma J, Ugboaja J, Iwuoha C, Nigeria. Akiode A, Oji E, et al. Knowledge and perception of the Nigerian Abortion Law by abortion seekers in south-eastern Nigeria. J

Obstet Gynaecol.

2011; 31(8): 763-6.

Okonta PI, Ebeigbe PN, Sunday-Adeoye I. Liberalization of abortion and reduction of abortion related morbidity and mortality in Nigeria. Acta Obstet Gyn Scan. 2010; 89(8): 1087-90.

Thapa S, Sharma SK, Khatiwada N. Women's knowledge of abortion law and availability of services in Nepal. J Biosoc Sci. 2014; 46(02): 266-77.

Martin CJ, Hyacenth G, Suite LS. Knowledge and Perception of Abortion and the Abortion Law in Trinidad and Tobago. Reprod Health Matter. 2007; 15(29): 97-107. Africa; Tunis, Tunisia; and

Bogota,

Colombia.

Socio-demographic characteristics of legal abortion seekers and Surveys and $n=681$ data from medical reasons for denied abortion records. care.

Nigeria.

Nepal.

Trinidad and Tobago.
Survey.
$\mathrm{n}=1411 \quad$ Married women in reproductive age.

Obstacles to abortion care reported by women.

To determine their knowledge and perceptions on the Nigerian Abortion Law. Information derived from the study may constitute major considerations in the future development of policies related to abortion management.

management.

of physicians on

abortion-related deaths,

liberalization of abortion

and its impact on the

reduction of maternal

deaths.

$$
\text { Survey. } \quad n=100 \quad \text { Abortion seekers. }
$$

\section{$\mathrm{n}=398 \quad$ Adult women who obtained first-trimester abortion services at public facilities.}
Women's awareness of the Survey. $\quad n=11727$ Women aged $15-45$ legal status of abortion and availability of abortion services.
People's knowledge and views on the abortion law.
Survey. $\quad \mathrm{n}=918$ years of age from the community.




\section{Continued}

\section{Mixed.}

Holcombe SJ, Berhe A, Cherie A. Personal Ethiopia. Beliefs and Professional Responsibilities: Ethiopian Midwives' Attitudes Toward Providing Abortion Services after Legal Reform. Stud Family Plann. 2015; 46(1): 73-95.

Clyde J, Bain J, Castagnaro K, Rueda M, Tatum Mexico city, C, Watson K. Evolving capacity and decision- Mexico* making in practice: adolescents' access to legal abortion services in Mexico City. Reprod Health Matter. 2013; 21(41): 167-75.
Factors associated with the Survey and willingness of mid-level interviews. providers to provide abortion services.

The effect of regulations and clinical attitudes and practice in the access of adolescent girls to information regarding termination of pregnancy and to abortion. $\mathrm{n}=188 \quad$ Survey: Midwives (surveys) attending to a national and $\mathrm{n}=12$ meeting, Interviews: (interviews) Midwifery students.

In-depth $\quad \mathrm{n}=61 \quad$ 1-Mystery client visits to interviews, adolescent access information focus $\quad s, n=4 \quad$ about legal abortion groups and mystery services, 2-Surveys of surveys. clients, $\mathrm{n}$ abortion clinic directors $=47$ and staff, 3-Survey of surveys. adolescents looking for a legal abortion.

\section{Review}

Raševic M, Sedlecky K. The abortion issue in Serbia. Serbia. Eur J Contracept Reprod Health Care.

To identify the causal Review. factors involved in the high 2009;14(6):385-90.

prevalence of induced abortion in Serbia.

${ }^{\star}$ City is specified because legal status of abortion is different across the country.

Table 2. Legality status of abortion in the countries of the included studies.

\begin{tabular}{|c|c|c|c|c|c|c|c|}
\hline Country. & $\begin{array}{c}\text { To save a } \\
\text { woman's life. }\end{array}$ & $\begin{array}{c}\text { To preserve a } \\
\text { woman's physical } \\
\text { health. }\end{array}$ & $\begin{array}{c}\text { To preserve a } \\
\text { woman's mental } \\
\text { health. }\end{array}$ & $\begin{array}{c}\text { In cases of } \\
\text { rape or incest. }\end{array}$ & $\begin{array}{l}\text { Because of fetal } \\
\text { impairment. }\end{array}$ & $\begin{array}{l}\text { For economic or } \\
\text { social reasons. }\end{array}$ & $\begin{array}{l}\text { On } \\
\text { request. }\end{array}$ \\
\hline \multicolumn{8}{|c|}{ Africa. } \\
\hline Botswana & $\mathrm{X}$ & $\mathrm{X}$ & $\mathrm{X}$ & $\mathrm{X}$ & $\mathrm{X}$ & & \\
\hline Burkina Faso & $\mathrm{X}$ & $\mathrm{X}$ & $\mathrm{X}$ & $\mathrm{X}$ & $\mathrm{X}$ & & \\
\hline Ethiopia & $\mathrm{X}$ & $\mathrm{X}$ & $\mathrm{X}$ & $\mathrm{X}$ & $\mathrm{X}$ & & \\
\hline Ghana & $\mathrm{X}$ & $\mathrm{X}$ & $\mathrm{X}$ & $\mathrm{X}$ & $\mathrm{X}$ & & \\
\hline Nigeria & $\mathrm{X}$ & $\mathrm{X}$ & $\mathrm{X}$ & & & & \\
\hline Tunisia & $\mathrm{X}$ & $\mathrm{X}$ & $\mathrm{X}$ & $\mathrm{X}$ & $\mathrm{X}$ & $\mathrm{X}$ & $\mathrm{X}$ \\
\hline \multicolumn{8}{|c|}{ Asia. } \\
\hline China & $\mathrm{X}$ & $\mathrm{X}$ & $\mathrm{X}$ & $\mathrm{X}$ & $\mathrm{X}$ & $\mathrm{X}$ & $\mathrm{X}$ \\
\hline India & $\mathrm{X}$ & $\mathrm{X}$ & $\mathrm{X}$ & $\mathrm{X}$ & $\mathrm{X}$ & $\mathrm{X}$ & \\
\hline Malaysia & $\mathrm{X}$ & $\mathrm{X}$ & $\mathrm{X}$ & & & & \\
\hline Nepal & $\mathrm{X}$ & $\mathrm{X}$ & $\mathrm{X}$ & $\mathrm{X}$ & $\mathrm{X}$ & $\mathrm{X}$ & $\mathrm{X}$ \\
\hline Vietnam & $\mathrm{X}$ & $\mathrm{X}$ & $\mathrm{X}$ & $\mathrm{X}$ & $\mathrm{X}$ & $\mathrm{X}$ & $\mathrm{X}$ \\
\hline \multicolumn{8}{|c|}{ Central and South America. } \\
\hline $\begin{array}{c}\text { Trinidad and } \\
\text { Tobago }\end{array}$ & $\mathrm{X}$ & $\mathrm{X}$ & $\mathrm{X}$ & & & & \\
\hline Colombia & $\mathrm{X}$ & $\mathrm{X}$ & $\mathrm{X}$ & $\mathrm{X}$ & $\mathrm{X}$ & & \\
\hline Mexico & $\mathrm{X}$ & $\mathrm{X}$ & $\mathrm{X}$ & $\mathrm{X}$ & $\mathrm{X}$ & $\mathrm{X}$ & $\mathrm{X}$ \\
\hline \multicolumn{8}{|c|}{ Europe. } \\
\hline Serbia & $\mathrm{X}$ & $\mathrm{X}$ & $\mathrm{X}$ & $\mathrm{X}$ & $\mathrm{X}$ & $\mathrm{X}$ & $\mathrm{X}$ \\
\hline
\end{tabular}

Obtained from: World Abortion Policies 2013, United Nations - Department of Economic and Social Affairs - Population Division [10]. 
Women were more leaned to be pro-choice than men (62\% vs $38 \%$ ), in contrast to Botswana, where women seemed to be more punitive than men, while in both cases negative attitudes towards abortion laws increased with age [12] [13].

On the other perspective, $17 \%$ of Nigerian women thought that the law was too restrictive and only $2 \%$ thought it was "alright" [14], while physicians from the same country considered that if complete legalization occurs, the access to the service would be hindered by social determinants and that quackery and promiscuity would increase. The latter was also perceived as a concern-together with HIV spread-in Botswana [13] [15], as a women mentioned:

"You can't make it legal for people to abort, because one, you compromise a lot of, you know, a lot of education that goes into trying to stop teenage pregnancies and trying to stop a lot of uh, extra-marital affairs. In the country we are trying to fight HIV and AIDS [...] you know people have to change their ways [...] sexual patterns and so on" [13].

In India, medical doctors raised their concern about the infringement of the Medical Termination of Pregnancy Act (MTP Act), which states to keep confidentiality of all the medical records of abortion. This was expressed because government authorities demand the access to abortion records during their monitoring visits to control sex selection under the Pre-Conception and Pre-Natal Diagnostic Techniques (PCPNDT) Act (2003). Moreover, doctors stated that sex selection was still occurring, but the fear to persecution and extortion for themselves and patients, especially after second-trimester abortions, was creating an environment of fear in which they preferred to deny abortions to women [16].

In Hong Kong, sexual intercourse with minors under 16 years is illegal and consequently, adolescent pregnant women looking for legal abortion fear the prosecution of their partners [17]. Seemingly, non-married Indian women can only obtain abortion due to impairment of mental health, whereas in Botswana there is a general perception that law is not accessible to any women, which is aggravated by the requirement of the signature of two doctors to perform an abortion on medical grounds or a conviction by the court in the case of rape, considering that most rapes go unreported [13].

\subsubsection{Health System Norms and Standards}

In different instances, abortion providers demand requirements outside the law that result in delays [9] [17] [18] [19] [20]. Parental or husband's consent/presence for adolescent/married women was required to perform the procedure in Mexico, Vietnam and Hong Kong [17] [18] [19]. In Colombia, authorizations by a judge or other types of documents (such as signatures and stamps) were demanded by doctors as a means to protect themselves from further legal proceeding, while in other case, the abortion was denied to a women due to institutional conscientious objection (which is illegal in Colombia] [20]. Indeed, six articles reflected that requirements for the procedure varied across facilities of the 
same county [17]-[22].

Quality of legal abortion services was an issue raised by interviewees in three studies. Teenage women from Hong Kong and abortion providers from South Africa said that women preferred to go to private clinics and pay higher fees to receive a personalized service with more privacy, less stigmatization, shorter waiting times and better pre and post-abortion counselling [17] [21].

Four women from Vietnam sought for second-trimester termination of pregnancy (TOPs) because they went to health services in the first trimester, but their pregnancy was not detected, while other two women received manual vacuum aspiration (MVA) during early pregnancy at a hospital, but the procedure was not effective and they had to appeal for a second-trimester TOP. In addition, second-trimester abortions have been traditionally performed using the Kovac's method $^{1}$ in this country, which is not recommended by the World Health Organization due to the increase of serious complications and is restricted by the law to a gestational age between 16 and 22 weeks, meaning that women between 12 and 16 weeks of gestation have to wait until they reach the proper time of pregnancy [19] [23].

A different situation was exposed by abortion providers from Nepal, as they were concerned about the increasing number of women presenting from complications of ineffective medical abortion whom had obtained the pills from private pharmacists and other uncertified health personnel. Women used this service because it was more geographically accessible and advantages were similar to that mentioned for private services [24].

\subsection{Service Delivery}

\subsubsection{Providers' Attitudes}

In 10 out of 15 countries, judgmental attitudes from health care workers (including midwives, general practitioners, gynecologist/obstetrician, nurses and other health staff) towards women looking for abortion services were described, frequently based on personal and/or religious beliefs. Health workers questioned the reasons to obtain abortions -even in cases of rape and fetal malformations-, created unjustified delays, put pressure in women to continue the pregnancy, called them killers, and put fetus' rights over women's rights [15] [16] [18] [20] [21] [24]-[29]. Some providers that showed negative attitudes towards abortion said that they would help women for monetary compensation or in their private clinics [16] [21].

Adolescents and unmarried women were particularly vulnerable to providers' negative attitudes, which seemed to be increased by the negative perceptions about premarital sex and use of abortion as an anticonception method [17] [18] [19] [21] [24] [27] [28]. A study from Mexico also showed that only half of the adolescents were offered to talk alone with doctors, and the amount and quality

${ }^{1}$ Kovac's method: a condom-covered catheter with saline solution is introduced into the cavity of the uterus in order to create strong pressure on the uterine cavity and induce labor. 
of information that was given to them during counselling was higher when they were accompanied by an adult [18].

Counselling practices varied significantly across countries and type of providers. Some midwifes used counselling to dissuade women from obtaining an abortion, which was done through delivering incorrect information, warning women about "the dangers of abortion", hiding information about providers and advising them to deliver the baby. General practitioners and gynecologist/obstetricians appeared to be more objective than midwives when delivering information to patients [18] [27]. Conversely, women who had received abortion in a private clinic in Malaysia (the only one willing to participate in the research) felt that the counselling they had received was clear, complete and given in a non-judgmental way, but they also said that in government hospitals abortion was considered to be illegal [29].

Some health providers refused to get involved in any step of the provision of abortion based in religious and conscientious objection [15] [21] [27] [29] and $65 \%$ of Ethiopian midwives believed that providers had the right to do so (26). Nevertheless, other providers expressed that they were facing contradictions between their personal beliefs and their professional duty, which was especially notorious when pregnancy was a result of rape or incest, to save a woman's life or in cases of fetal malformations [21] [27]:

"Personally, I don't want to do abortion, but if a woman came to me to have an abortion, according to the legal exceptions that make abortion legal, I would do it. Even if it is killing the baby, but she came being pregnant from her father or brother, it is hard to live with that. Even having a baby from a father or brother is not legal. So, this is a sin, and performing an abortion is also a sin. I think that when I weigh it, performing an abortion for her is much better than letting her live with that baby. Even if I say I will not perform an abortion, I know that this will not stop this lady from aborting. She will go to other places that are not safe" [26].

In the same way, colleagues seemed to have an important impact in the willingness of health care workers to provide the service. For instance, $37 \%$ of Ethiopian midwives felt that colleagues would not respect them if they offered abortion services [26], while Colombian and South African abortion providers expressed that that their colleagues referred to them as "murderers" or "baby killers", making them feel stigmatized and burned out [20] [21], as a provider recounted:

"They make it difficult for you. They spread the word in the community...and also isolate you. Where you' re supposed to be peers and working hand in hand and you can become extremely unhappy. You'd often find midwifes not providing abortions because they fear the victimization, being stigmatized, being isolated from their peers, and also within the community itself ${ }^{p}$ [21].

Unsafe abortion and the resulting high burden of maternal deaths were strong reasons for providing the service or referring the patient to a practitioner that 
would do it, even when health care workers were against abortion. Consequently, practitioners were aware that denying the provision of the service would not prevent women from having an abortion, but rather it would force them to look for it elsewhere [14] [19] [21] [24] [26] [27]. In contrast, Ethiopian midwives considered that this rationale could not be used to maintain or expand the access to abortion as the rates of maternal mortality declined [26] and $48.5 \%$ of Nigerian physicians considered that abortion legalization would not reduce them at all [14]. Some health care workers expressed that more attention was being given to abortion services than to comprehensive contraception services in the national health agenda [21] [24].

\subsubsection{Provider Training and Support}

Training about abortion varied between countries and health providers. In Mexico $79 \%$ of the staff working in abortion facilities received training about it [18], while $49 \%$ of Ethiopian midwives said to have been trained and $78 \%$ were interested in receiving further training [26]. All the gynecologists interviewed in India had been taught about the MTP Act, but some of them had mistaken ideas about it [16]. On the other hand, South African abortion providers said that although training was easily accessible, the sessions were often canceled due to lack of assistance, which was justified by shortage of staff in health facilities and stigmatization of those attending [21]. Ghanaian health workers recounted that the managers of the health facilities-often senior doctors-discouraged the provision of abortion, the availability of medical equipment and the training of the staff [27].

Only 37\% of Ethiopian midwives knew the instances for legal abortion [26], while lack of knowledge about the local law was described as the reason for the denial of abortion to a woman in Colombia [20] and was related to unsupportive attitudes towards abortion in South Africa [21]. In addition, providers in Nepal confounded the legislation about abortion with the social standards related to it for conditions such as the marital status of the women, and requirement of husband's consent, as a health care administrator expressed [24]:

"It's illegal for unmarried women to my knowledge... because, you know; the culture does not allow it" [24].

\subsubsection{Availability}

Unavailability of the abortion services occurred in different levels; scarcity of provider facilities, shortage of staff to perform the procedure, overcrowded services, unwillingness of health staff to provide the service and lack of adequate pre- and post-abortion counselling were all described [9] [15] [16] [20] [21] [24] [29]. This barriers lead women to explore other options, for instance, seven of the interviewees in Botswana mentioned crossing the national border to South Africa as a common option to access safe abortion services [13].

Delays in getting appointments were mentioned in Colombia and Mexico. In the first one, average waiting time for the procedure was 16 days (range 2 to 44 
days) [20] while in the second, both medical and surgical abortion require two appointments, which are available only on week-days, with a waiting time between hours and 15 days depending on the client load. Interestingly, 16\% of women said that getting appointments had been difficult, but the only variable associated with this barrier was education; women with a primary or lower level of education had 4.1 (CI95\% 1.8 - 9.5) times more risk of reporting this difficulty than women with a high school education [30].

An important aspect for availability in India was the time spent by doctors to fill an extensive form manually and then submit the information online, as there were frequent problems with the internet connection and the platform performance and the whole process was considered time consuming in an already overcrowded service [16]. Another study also made in India found that the perceived availability of the abortion services was greater in women who knew an abortion method and smaller in women who correctly knew a facility that provided abortion, the latter probably related with the cost of the service [31].

\subsubsection{Distribution}

Facilities providing abortion were less frequent in rural than in urban areas [20] [24] [30] [31] and in Botswana, women considered that people in distant areas were less comprehensive regarding abortion termination [13]. Additionally, women from rural areas may travel to obtain abortion, but this increases the costs and entails other difficulties [19] [20]. For instance, women living outside Mexico City are prioritized to get appointments, but they were found to have a 2.8 times higher risk of difficulty arranging transportation, and they may have to find a place to stay in the city overnight [30].

\subsubsection{Affordability}

The direct and indirect costs of abortion are an important determinant for the access to it in low and middle income countries, as shown in nine of the articles [22]. Cost was seen as a barrier for the access to abortion for women with low resources in two studies [9] [12], while in other four, women delayed the procedure in order to get the money [17] [24] [25] [29], considering that sometimes providers increase the cost as the pregnancy progresses [13] [19] [25]. However, physicians from Vietnam justified the high fees as a way to discourage women from using abortion as a contraception method [19].

In a study performed in the area of Bihar and Jharkhand, India, the perceived affordability was a general concern and it was higher in women from the general caste (compared to scheduled tribe, $\mathrm{p}=0.004$ ), other religions (compared to Hindu, $\mathrm{p}=0.04)$ and null gravid women $(\mathrm{p}=0.048)$ [31]. In contrast, an abortion provider from another study performed in Western Maharashtra said:

"This area is very much developed and many people have money in hand, so they are ready to pay any-thing; they are not bothered about the fees. So the abortion rates are also high in this area. And they openly ask us for sex selection" [16]. 


\subsection{Women's Abortion Care-Seeking Behavior}

\subsubsection{Delays and Obstacles to Search for Abortion Services}

Women described multiple-and overlapping-factors influencing the occurrence of delays for the receipt of abortion services. Delays finding out pregnancy, deciding to have an abortion, obtaining the money to cover the costs, finding a provider and completing requirements-such as reporting rape-were all described in different studies [9] [13] [16] [19] [20] [29]. As a consequence, a multicenter study found that advanced gestational age was the cause for denial of abortion in 20\% of women in South Africa, 7\% in Tunisia, 26\% in Nepal and 2\% in Colombia [9].

A study exploring the reasons for second-trimester abortions in Vietnam found that $80 \%$ of these women detected the pregnancy after 12 weeks and $20 \%$ of women required more than 1 month to make the decision [19], frequently because they wanted to continue the pregnancy but the situation was unfavorable, they had to persuade their partners, the partner denied responsibility for the pregnancy or pregnancy was used as an unsuccessful mean to force marriage [16] [19] [27] [29].

Getting time out of work was the most frequent obstacle to obtaining abortion in México, reported 26\% of all participants. Single (OR 2.5, 95\%CI $1.4-4.3$ ) as well as separated or divorced women (OR $2.9,95 \% \mathrm{CI} 1.0$ - 8.3) were more likely to report this obstacle than married women, while on the contrary, women with a middle school education were less likely to report it (OR 0.4, 95\%CI $0.2-0.8$ ). Opposition to abortion by the partner or other family member (19\%) was the second most frequent obstacle, and was only related to being separated or divorced (compared to married women, OR 3.5, 95\%CI 1.3 - 9.6) [30].

On the whole, women from Mexico with a primary or lower level of education (OR 2.1, 95\%CI 1.1 - 4.0) were more likely to report a higher number of obstacles, as well as both single (OR 2.1, 95\%CI 1.4 - 3.2) and separated/divorced (OR 3.4, 95\%CI 1.4 - 8.6) women, compared to married women [30].

Partners' role in the abortion decision-making process was reported in three articles. The final decision to have an abortion by Indian married women was made both by themselves (70\%) and their husbands (74\%) [31]. In Ghana, partners-when they were aware of the pregnancy-where the ones who suggested or demanded women to get an abortion, according to providers and post-abortion patients, but not male partners. In cases when women did not want the pregnancy, they would tell their partners about expecting him to take the decision to have an abortion. Another option was to hide the both the pregnancy and the abortion, since in Ghanaian culture, a women who wants to get an abortion is suspected to have been adulteress [28].

\subsubsection{Knowledge of Services}

Sources of information and exposure to mass media may influence the degree and quality of knowledge about abortion and therefore have an impact in the decision-making process, as showed by four studies. Firstly, most of women 
from Malaysia obtained information about the abortion procedure and providers from friends or colleagues, but the information they got was frequently superficial and inadequate. They also said that the information from media was rare and that difficulties finding assertive information caused anxiety to them [29]. Secondly, cultural barriers have blocked the dissemination of information about abortion in Botswana, while the pro-life argument has been widely spread through anti-abortion campaigns [13].

Likewise, the majority of women (87.3\%) in Bihar and Jharkhand, India had no information about abortion, which was probably related to the fact that most of them never used to watch television $(84.8 \%)$, listen to the radio $(86.1 \%)$ or read newspapers (93.5\%). The exposure to other sources of information like at a women's club or community meetings and the market was also infrequent. Despite this, the most important source for those who had received any information was on the community level (14.2\%), followed by family and friends (4.6\%), health providers $(4.4 \%)$ and lastly, mass media (4.3\%). The majority of women (83.1\%) in this study had a low living standard [31], which was also said in Nepal and India to be the population that most often comes looking for the service during the second trimester due to lack of information [16] [24].

Knowledge about the local abortion law, locations that provide abortion, abortion methods, possible risks of the procedure and post abortion care were all mentioned in eight articles as important aspects of in order to guarantee the access to safe abortion services [12] [13] [14] [16] [21] [24] [29] [31]. Furthermore, women who had obtained abortion in Malaysia said that dissemination of information from a valid source would increase public awareness and knowledge about this issue [29]. Consequently, providers from Nepal also recognized that after legalization, confidence in the abortion services had increased, which is reflected in an increasing proportion of women looking for abortion services in legal facilities and consulting earlier for abortion-related complications [24].

Lack of awareness about the abortion law was reported as a cause for second-trimester abortions by physicians in Nepal [24], while the legal status of abortion was known by $32 \%$ to $44 \%$ of the participants in studies performed in Nigeria, India, Nepal and Trinidad and Tobago, as shown in Table 3. Despite the fact that only $10.7 \%$ of women have heard about medical abortion and only $0.8 \%$ knew about surgical abortion, knowing an abortion method was significantly associated with favorable attitudes toward abortion in Indian women [31].

Only $46.2 \%$ of women in India knew about a source of abortion services, while $89 \%$ of women who had an abortion within the past 3 years, consulted a doctor on how to obtain it. Most of the latter women were informed about providers by their husbands (61\%) or other close relatives (50\%) [31]. Since Malaysian women had the perception that governmental hospitals do not provide the service as it was illegal and they did not know any providers, situations such as going to a few clinics before finding a provider and resorting to use a traditional method for inducing abortion were mentioned [29]. 
Table 3. Knowledge about the abortion law by general populations of four low and middle income countries.

\begin{tabular}{|c|c|c|}
\hline Country. & Population. & Knowledge about the law. \\
\hline India [31] & $\begin{array}{l}\text { Married women } \\
\text { in reproductive } \\
\text { age. }\end{array}$ & $\begin{array}{l}35.8 \% \text { of women knew that abortion was legal, } 4.7 \% \text { thought that if was legal if the woman was married, } 47.9 \% \\
\text { thought that it was illegal and } 11.6 \% \text { did not know. } 71.1 \% \text { of women had incorrect knowledge about the } \\
\text { gestational limits for MTP, } 1.9 \% \text { had correct knowledge and } 27.0 \% \text { knew no information about it. }\end{array}$ \\
\hline $\begin{array}{l}\text { Trinidad } \\
\text { and Tobago } \\
{[12]}\end{array}$ & $\begin{array}{l}\text { General } \\
\text { population. }\end{array}$ & $\begin{array}{l}44 \% \text { correctly said that abortion was legal under certain circumstances, } 38 \% \text { thought it was completely illegal, } 5 \% \\
\text { did not know about the existence of the law and } 13 \% \text { had no idea. } 57.7 \% \text { of Hindus knew about the law, while } \\
44.3 \% \text { did and other religions felt in between those two. }\end{array}$ \\
\hline Nigeria [14] & $\begin{array}{l}\text { Women looking } \\
\text { for abortion. }\end{array}$ & $\begin{array}{l}32 \% \text { of women knew about the existence of the law. } \\
\text { Knowledge about the legality of abortion was not statistically related neither with the number of previous } \\
\text { pregnancy terminations nor the education status }(\mathrm{p}>0.05) \text {. }\end{array}$ \\
\hline Nepal [36] & $\begin{array}{l}\text { Women in } \\
\text { reproductive age. }\end{array}$ & $\begin{array}{l}\text { In total, } 38.7 \% \text { ( } 95 \% \text { CI: } 37.8,39.6 \text { ) of women were aware of the legal status of abortion. } \\
\text { Awareness was significantly higher in urban than in rural areas ( } 47.9 \% \text { vs } 37.1 \%, \text { OR } 0.8,95 \% \text { CI } 0.6-0.9) \text {. } \\
\text { Knowledge increased from } 22.3 \% \text { in the first wealth quintile to } 54.7 \% \text { in the fifth wealth quintile (OR } 2.5,95 \% \mathrm{CI} \\
2.0 \text { - 3.3) } \\
\text { Knowledge about the law increased significantly with the level of education compared to women with no } \\
\text { education. More than two thirds ( } 69.4 \% \text { ) of women with a high school or higher education knew about the } \\
\text { abortion law, compared with } 20.4 \% \text { in women with no education (OR } 8.6,95 \% \mathrm{CI} 6.8-10.9 \text { ) } \\
\text { Comparison between the results ( } 2011 \text { ) and a survey from } 2006 \text { : Awareness about the existence of an abortion law } \\
\text { increased significantly in nine of ten country sub-regions. The increase was similar in rural and urban areas and } \\
\text { varied across ages. } \\
\text { The increase of awareness was higher in women with higher levels of education and in the higher economic strata, } \\
\text { while among women with lower educational levels or lower economic strata there was modest or no increase. }\end{array}$ \\
\hline
\end{tabular}

\subsubsection{Socio-Cultural Determinants}

Abortion-related stigma on social and religious grounds was reported in seven (32\%) of the articles (Table 4). Abortion was seen as a shameful act both for women and providers, while stigmatization due to irresponsible sexual behavior was mentioned both as a cause of abortion and as a reason for searching abortion services secretly.

The study performed in the general population of Trinidad and Tobago showed that $15.4 \%$ were in favor of abortion no matter the circumstances, $49.0 \%$ opposed completely and $35.6 \%$ accepted it depending on the circumstances. Abortion was often accepted for cases of rape, incest, and risk to the woman's life, even among those that were anti-choice [12].

The study performed in Botswana found that the role of women and the significance of children in the society were important aspects for the acceptance of abortion. First, children were seen as a reason for pride and respect that confer social standing in African cultures, nourished by the fact that they can be used for labor and financial support later in life. Secondly, the country still preserved an oppressive patriarchal structure, where it was mandatory for women to bear children and having as many children as possible is seen as a way to overcome the inferior position of women in society. Additionally, abortion was considered unnecessary because in the case of an unwanted pregnancy, it is common to transfer the child between family members or from one family to another. However, this tradition appears to have been stablished as a result of an anti-abortion sentiment in the community and it does not take into account than the women's physical and mental health [13]. 
Table 4. Social and religious stigma related to abortion in low and middle income countries.

\begin{tabular}{|c|c|c|c|}
\hline Country. & Perspective. & Social stigma. & Religious stigma. \\
\hline Nepal [24] & AP. & $\begin{array}{l}\text { Stigma and secrecy regarding abortion remain after legalization. } \\
\text { Women fear to disclose previous abortions during medical visits, } \\
\text { especially if it was an illegal abortion or an abortion outside the } \\
\text { gestational age limits. Unmarried women hide the history about } \\
\text { previous abortion due to fear to judgment from providers. }\end{array}$ & \\
\hline $\begin{array}{l}\text { Malaysia } \\
{[29]}\end{array}$ & W. & $\begin{array}{l}\text { Requesting abortion (information and procedure) to providers is } \\
\text { difficult for women due to stigma related to abortion. }\end{array}$ & $\begin{array}{l}\text { Women consider abortion as a "sin" and fear people } \\
\text { talking behind their backs. }\end{array}$ \\
\hline $\begin{array}{l}\text { Colombia } \\
{[20]}\end{array}$ & $\mathrm{W}$ & $\begin{array}{l}\text { The society does not understand the abortion law and has unrecognized } \\
\text { and unresolved ethical, medical and legal issues regarding abortion. }\end{array}$ & \\
\hline $\begin{array}{l}\text { Vietnam } \\
{[19]}\end{array}$ & W. & $\begin{array}{l}\text { Women resort to have an abortion due to social consequences of } \\
\text { keeping it. In Vietnamese society, premarital intercourse is } \\
\text { considered a shame for both the family and the entire clan. }\end{array}$ & \\
\hline $\begin{array}{l}\text { Ghana } \\
{[27]}\end{array}$ & AP. & $\begin{array}{l}\text { Social pressure and labelling on doctors who provide abortion } \\
\text { leads them to denying or misclassifying it. }\end{array}$ & $\begin{array}{l}\text { Religious beliefs are a barrier both coming from the } \\
\text { health personnel and from the community. Churches } \\
\text { spread the conception that abortion is bad to the } \\
\text { community. }\end{array}$ \\
\hline $\begin{array}{l}\text { Botswana } \\
{[13]}\end{array}$ & W. & $\begin{array}{l}\text { The stigma about abortion is related to the association of } \\
\text { unwanted pregnancies with irresponsible sexual intercourse and } \\
\text { unacceptable promiscuity. }\end{array}$ & $\begin{array}{l}\text { Religiosity influenced the perceptions of women } \\
\text { about abortion. The Catholics believe that the soul } \\
\text { enters the body after conception, which makes } \\
\text { abortion unacceptable at any gestational age. } \\
\text { However, women face an ambivalence between their } \\
\text { religious and personal beliefs }\end{array}$ \\
\hline India [31] & W. & $\begin{array}{l}\text { Societal norms and individual attitudes were bot not seen as } \\
\text { favorable towards abortion. }\end{array}$ & $\begin{array}{l}\text { Women from other religions were statistically more } \\
\text { likely to have a favorable perception towards abortion } \\
\text { than Hindu women }(\mathrm{p}=0.01) \text {. }\end{array}$ \\
\hline
\end{tabular}

AP: Abortion providers, W: Women.

\subsection{Abortion in Serbia}

Abortion in Serbia has been legal since 1969 and it is requested directly to gynecologists, who have the legal obligation to perform it. The cost of abortion is higher than the yearly cost of effective contraception and the price is the same in private and public facilities, but the physician is only paid to perform it in private clinics. However, abortion in Serbia is widely used and socially accepted nowadays; $24.3 \%$ of adolescents are taught by their parents about induced abortions and nearly half (46.3\%) knew that their mothers have used abortion as a birth control method. The reason for this behavior is that women thought that abortion was less harmful to health and less complicated to use than any contraceptive method, as shown in one study that found that $38.7 \%$ of health staff had never used contraception, whereas $59.0 \%$ of them or their partners had had an induced abortion (1.3 abortions on average) [22].

\subsection{Strategies and Facilitators}

The strategies and facilitators proposed to address abortion barriers, either stated in the results or the discussion of the studies are shown in Table 5. 
Table 5. Strategies and facilitators to increase the access to safe abortion services.

\begin{tabular}{|c|c|c|c|}
\hline Category & Subcategory & Strategies and facilitators & Ref. \\
\hline \multirow{12}{*}{$\begin{array}{l}\text { Law and } \\
\text { health } \\
\text { system }\end{array}$} & \multirow{7}{*}{$\begin{array}{l}\text { Abortion laws } \\
\text { and justice } \\
\text { system. }\end{array}$} & Political will regarding abortion. & [27] \\
\hline & & Equality of the access to the laws to all women. & {$[16]$} \\
\hline & & Creation of laws to improve social barriers for the access to abortion and gender inequality. & [16] \\
\hline & & Laws to facilitate the access to abortion (transportation of women, reduction of the number of & {$[13][30]$} \\
\hline & & visits required). Legislation for increasing the availability of abortion services and supplies. & [16] [29] \\
\hline & & Approval of abortion medication (misoprostol and mifepristone). Adolescents' autonomy for & [29] \\
\hline & & decision making. & {$[18]$} \\
\hline & \multirow{6}{*}{$\begin{array}{l}\text { Health system } \\
\text { norms and } \\
\text { standards }\end{array}$} & Consultation of women and general population about their acceptance of abortion. Supervision & {$[12]$} \\
\hline & & of the quality of abortion services. & {$[20][27]$} \\
\hline & & Creation of national abortion provision standards and protocols. Ensure privacy and & {$[18][24][27]$} \\
\hline & & confidentiality of women during all steps of abortion care. & {$[18]$} \\
\hline & & Strengthen pre and post abortion counselling. & [21] [24] [29] \\
\hline \multirow{20}{*}{$\begin{array}{l}\text { Access to } \\
\text { safe } \\
\text { abortion } \\
\text { services. }\end{array}$} & & Task shifting from specialized to mid-level providers (also increases availability). & {$[16][21]$} \\
\hline & \multirow[t]{2}{*}{$\begin{array}{l}\text { Providers' } \\
\text { attitudes. }\end{array}$} & Normalizing abortion as a health service. & [24] [27] \\
\hline & & Values clarification workshops. & {$[21][24][27]$} \\
\hline & \multirow{7}{*}{$\begin{array}{l}\text { Provider } \\
\text { training and } \\
\text { support. }\end{array}$} & Education about the abortion legislation for health managers. & {$[27]$} \\
\hline & & Greater advocacy of legal abortion in the health system and to the society. & [27] \\
\hline & & $\begin{array}{l}\text { Education of health personnel including: legislation, requirements to access to abortion, } \\
\text { surgical and medical abortion procedures. }\end{array}$ & $\begin{array}{l}{[13][20][21][24]} \\
{[26][27][28][29]}\end{array}$ \\
\hline & & Expose providers to the international abortion standards and declarations. & [27] \\
\hline & & Training about pre and post abortion counselling. & [24] [30] \\
\hline & & Training of pharmacists on how to deal with women looking for abortion services. & {$[24]$} \\
\hline & & Abortion-specialized centers. & [21] \\
\hline & \multirow{4}{*}{ Availability. } & $\begin{array}{l}\text { Promotion of facilities that provide abortion (e.g. abortion logo for facilities in } \\
\text { Vietnam). }\end{array}$ & [27] \\
\hline & & Increase the involvement of the public sector in provision of the service. & {$[31]$} \\
\hline & & Abortion provision on weekends and after work hours. & [30] \\
\hline & & Reduce waiting times. & {$[30]$} \\
\hline & \multirow[t]{3}{*}{ Distribution. } & Increasing the number of abortion providers, especially in rural areas. & {$[16][24]$} \\
\hline & & Reduction and standardization of costs. & [13] \\
\hline & & Lower cost for poor women. & [13] [16] \\
\hline & \multirow[t]{3}{*}{ Affordability. } & Promote the use of medical abortion. & [31] \\
\hline & & Reimburse for unused medication on follow up. & [29] \\
\hline & & No charge for follow up visits. & [29] \\
\hline \multirow{5}{*}{$\begin{array}{l}\text { Women's } \\
\text { abortion } \\
\text { care seeking } \\
\text { behavior. }\end{array}$} & Attitudes & Empowerment of women (increase economic and decision independence). & [13] [31] \\
\hline & $\begin{array}{l}\text { towaras looking } \\
\text { for services. }\end{array}$ & Increase awareness about unsafe abortion. & [31] \\
\hline & \multirow{3}{*}{$\begin{array}{c}\text { Knowledge of } \\
\text { services. }\end{array}$} & Education of general population about: abortion legislation, providers, methods and risks. & $\begin{array}{l}{[14][19][20][29]} \\
{[31]}\end{array}$ \\
\hline & & Clarification of misconceptions about abortion to the general population. & [19] [24] \\
\hline & & $\begin{array}{l}\text { Design of educational material that is understandable for all population (including illiterate } \\
\text { women). }\end{array}$ & [31] \\
\hline
\end{tabular}


Pro-choice information divulgated trough massive media must be greater than anti-choice propaganda.

Use providers of public health services (such as vaccination and antenatal care) as educational channels.

Social determinants.

Use community channels to deliver information about abortion and increase awareness.

[29] [31]

Main findings and conclusions of the literature: The database search yield 199 articles in MEDLINE. 24 in Scopus and 38 in Scielo. A total of 22 articles including 15 countries from Africa $(n=6)$, Asia $(n=5)$, Central and South America $(n=3)$ and Europe $(n=1)$. The legal status of abortion in each of these countries was studied and described. For the analysis of the information, three categories of deepening were established: Laws and policies, Service delivery and Women's abortion care-seeking behavior. Conclusion: the determinants of access to abortion in low and middle income countries are convoluted as multiple delays and barriers usually overlap. Similarly, stigmatization has a great impact across all the steps of abortion provision. Multiple facilitators were proposed in the three aspects of abortion provision, but they need to be adjusted depending on the context of each country.

\section{Discussion.}

This review shows that socio-cultural and health-care-related barriers occurred in all countries included, regardless of the degree of decriminalization of abortion. All the religions mentioned in the studies seemed to have the same effect on abortion, considering it a "sin" and making it a punishable act that caused stigmatization of women who used it.

In contrast, the normalization of abortion as a birth control method in Serbia also shows that when abortion is widely accessible but it is not the complement of effective family planning services, it can become overused, although the impact of this issue on maternal health has not been studied in the country [22].

Stigmatization coming from both colleagues and the society is a reason why abortion providers remain clandestine-even when it is performed under legal instances-similarly to the situation reported in rural Canada [32] [33]. Therefore, it is important to constantly implement strategies such as values clarifications workshops to decrease negative attitudes about abortion among health staff [21]. The Nepali the Safe Abortion Logo could be another strategy to overcome the stigma over abortion providers by normalizing abortion as a medical service. Besides, the thoughtful implementation of this logo outside the abortion-provider facilities has made it widely recognized, even for vulnerable populations like illiterate women [34].

Women's expected submission to male partners and to their role in society as child bearers continue to occur in traditionally patriarchal societies [13] [24] [28]. Therefore, abortion policy makers need to take into account the realistic freedom with which women decide over their reproduction and make adjustments to current laws to decrease gender inequality [13] [27] [35]. However, the effect of the disadvantageous position of women as a barrier to the access to abortion can be underestimated, since it is part of the status quo of these societies. Also, women in this position may not look for abortion services in the first place.

The results of this review are somewhat similar to the systematic review performed in high income countries when it comes to the barriers related to the 
health system and the strong influence that the providers' attitudes have in them. In both reviews, judgmental attitudes of providers had a negative effect in the women's experience with abortion services and physicians struggled with ambivalent feelings about the provision of abortion [4].

Conversely, social determinants of access to abortion were markedly different in this review compared with the systematic review including high income countries. First, stigma was found in this review as problem that goes across all the aspects of abortion provision rather being limited to the discrimination of providers. Secondly, in the review by Dorian and Nancarrow, delays to timely access to abortion were mostly related to the availability of appointments and the choice of providers, while in this review, there were multiple delays occurring before the woman reaches the facility, while afterwards, the delays were mostly related to the willingness of the health workers to provide the service [4]. On the whole, findings show that the determinants of the access to abortion services are markedly different in low and middle income countries compared with high income countries, as well as among countries in each of these groups.

This finding suggest that liberal abortion laws need to be implemented altogether with political initiatives to guarantee the access to the service, which should include strategies to increase awareness and knowledge about safe abortion, which would help decrease the stigma surrounding the issue [31].

Education programs must be comprehensive and include the legislation, methods, providers and possible consequences of abortion. However, this program also need to take into consideration that women in the most vulnerable populations may not be exposed to mass media, as shown in India, which makes community channels the best disseminators of information in rural and/or segregated areas.

This review included articles from diverse countries, with a mixture between qualitative and quantitative studies, which gives a broad perspective on the situation of access to abortion in low and middle countries. However, each of the countries included has a very particular situation regarding abortion according to its own socio-cultural background, hence the results are quite heterogeneous. Other limitations are that most of the articles covered a particular area of a country or only the perspective of either women or providers.

\section{Conclusion}

In conclusion, the determinants of access to abortion in low and middle income countries are convoluted as multiple delays and barriers usually overlap. Similarly, stigmatization has a great impact across all the steps of abortion provision. Multiple facilitators were proposed in the three aspects of abortion provision, but they need to be adjusted depending on the context of each country.

\section{References}

[1] Say, L., Chou, D., Gemmill, A., Tunçalp, Ö., Moller, A.-B., Daniels, J., et al. (2017) Global Causes of Maternal Death: A WHO Systematic Analysis. The Lancet Global 
Health, 2, e323-e333.

[2] Culwell, K.R. and Hurwitz, M. (2013) Addressing Barriers to Safe Abortion. International Journal of Gynecology \& Obstetrics, 121, S16-S19.

[3] Henderson, J.T., Puri, M., Blum, M., Harper, C.C., Rana, A., Gurung, G., et al. (2013) Effects of Abortion Legalization in Nepal, 2001-2010.

[4] Doran, F. and Nancarrow, S. (2015) Barriers and Facilitators of Access to First-Trimester Abortion Services for Women in the Developed World: A Systematic Review. The Journal of Family Planning and Reproductive Health Care, 41, 170-180. https://doi.org/10.1136/jfprhc-2013-100862

[5] Harries, J., Gerdts, C., Momberg, M. and Foster, D.G. (2015) An Exploratory Study of What Happens to Women Who Are Denied Abortions in Cape Town, South Africa. Reproductive Health, 12, 21. https://doi.org/10.1186/s12978-015-0014-y

[6] Finer, L. and Fine, J.B. (2013) Abortion Law around the World: Progress and Pushback. American Journal of Public Health, 103, 585-589. https://doi.org/10.2105/AJPH.2012.301197

[7] Grimes, D.A., Benson, J., Singh, S., Romero, M., Ganatra, B., Okonofua, F.E., et al. (2006) Unsafe Abortion: The Preventable Pandemic. The Lancet, 368, 1908-1919. https://doi.org/10.1016/S0140-6736(06)69481-6

[8] Myers, J.E. and Seif, M.W. (2010) Global Perspective of Legal Abortion-Trends Analysis and Accessibility. Best Practice \& Research: Clinical Obstetrics \& Gynaecology, 24, 457-466. https://doi.org/10.1016/j.bpobgyn.2010.04.002

[9] Gerdts, C., DePiñeres, T., Hajri, S., Harries, J., Hossain, A., Puri, M., et al. (2014) Denial of Abortion in Legal Settings. The Journal of Family Planning and Reproductive Health Care, 41, 161-163.

[10] United Nations-Department of Economic and Social Affairs-Population Division. World Abortion Policies 2013.

[11] Benson, J. (2005) Evaluating Abortion-Care Programs: Old Challenges, New Directions. Studies in Family Planning, 36, 189-202.

https://doi.org/10.1111/j.1728-4465.2005.00061.x

[12] Martin, C.J., Hyacenth, G. and Suite, L.S. (2007) Knowledge and Perception of Abortion and the Abortion Law in Trinidad and Tobago. Reproductive Health Matters, 15, 97-107. https://doi.org/10.1016/S0968-8080(07)29301-2

[13] Smith, S.S. (2013) The Challenges Procuring of Safe Abortion Care in Botswana. African Journal of Reproductive Health, 17, 43-55.

[14] Adinma, E., Adinma, J., Ugboaja, J., Iwuoha, C., Akiode, A., Oji, E., et al. (2011) Knowledge and Perception of the Nigerian Abortion Law by Abortion Seekers in South-Eastern Nigeria. Journal of Obstetrics and Gynaecology, 31, 763-766. https://doi.org/10.3109/01443615.2011.593645

[15] Okonta, P.I., Ebeigbe, P.N. and Sunday-Adeoye, I. (2010) Liberalization of Abortion and Reduction of Abortion Related Morbidity and Mortality in Nigeria. Acta $O b$ stetricia et Gynecologica Scandinavica, 89, 1087-1090. https://doi.org/10.3109/00016341003801649

[16] Potdar, P., Barua, A., Dalvie, S. and Pawar, A. (2015) "If a Woman Has Even One Daughter, I Refuse to Perform the Abortion": Sex Determination and Safe Abortion in India. Reproductive Health Matters, 23, 114-125. https://doi.org/10.1016/j.rhm.2015.06.003

[17] Hung, S.L. (2010) Access to Safe and Legal Abortion for Teenage Women from Deprived Backgrounds in Hong Kong. Reproductive Health Matters, 18, 102-110. 
https://doi.org/10.1016/S0968-8080(10)36527-X

[18] Clyde, J., Bain, J., Castagnaro, K., Rueda, M., Tatum, C. and Watson, K. (2013) Evolving Capacity and Decision-Making in Practice: Adolescents' Access to Legal Abortion Services in Mexico City. Reproductive Health Matters, 21, 167-175. https://doi.org/10.1016/S0968-8080(13)41708-1

[19] Gallo, M.F. and Nghia, N.C. (2007) Real Life Is Different: A Qualitative Study of Why Women Delay Abortion until the Second Trimester in Vietnam. Social Science \& Medicine, 64, 1812-1822. https://doi.org/10.1016/j.socscimed.2007.02.005

[20] Amado, E.D., García, M.C.C., Cristancho, K.R., Salas, E. and Hauzeur, E.B. (2010) Obstacles and Challenges Following the Partial Decriminalisation of Abortion in Colombia. Reproductive Health Matters, 18, 118-126. https://doi.org/10.1016/S0968-8080(10)36531-1

[21] Harries, J., Stinson, K. and Orner, P. (2009) Health Care Providers' Attitudes towards Termination of Pregnancy: A Qualitative Study in South Africa. BMC Public Health, 9, 296. https://doi.org/10.1186/1471-2458-9-296

[22] Raševic, M. and Sedlecky, K. (2009) The Abortion Issue in Serbia. The European Journal of Contraception \& Reproductive Health Care, 14, 385-390. https://doi.org/10.3109/13625180903215422

[23] Phan, T. and NK, T.H. (2008) Second Trimester Abortion in Vietnam: Changing to Recommended Methods and Improving Service Delivery. Reproductive Health Matters, 16, 145-150.

[24] Puri, M., Lamichhane, P., Harken, T., Blum, M., Harper, C.C., Darney, P.D., et al. (2012) “Sometimes They Used to Whisper in Our Ears": Health Care Workers' Perceptions of the Effects of Abortion Legalization in Nepal. BMC Public Health, 12, 297. https://doi.org/10.1186/1471-2458-12-297

[25] Ouédraogo, R. and Sundby, J. (2014) Social Determinants and Access to Induced Abortion in Burkina Faso: From Two Case Studies. Obstetrics and Gynecology International, 2014, Article ID: 402456.

[26] Holcombe, S.J., Berhe, A. and Cherie, A. (2015) Personal Beliefs and Professional Responsibilities: Ethiopian Midwives' Attitudes toward Providing Abortion Services after Legal Reform. Studies in Family Planning, 46, 73-95. https://doi.org/10.1111/j.1728-4465.2015.00016.x

[27] Aniteye, P. and Mayhew, S.H. (2013) Shaping Legal Abortion Provision in Ghana: Using Policy Theory to Understand Provider-Related Obstacles to Policy Implementation. Health Research Policy and Systems, 11, 23.

https://doi.org/10.1186/1478-4505-11-23

[28] Schwandt, H.M., Creanga, A.A., Adanu, R.M., Danso, K.A., Agbenyega, T. and Hindin, M.J. (2013) Pathways to Unsafe Abortion in Ghana: The Role of Male Partners, Women and Health Care Providers. Contraception, 88, 509-517. https://doi.org/10.1016/j.contraception.2013.03.010

[29] Tong, W.T., Low, W.Y., Wong, Y.L., Choong, S.P. and Jegasothy, R. (2012) Exploring Pregnancy Termination Experiences and Needs among Malaysian Women: A Qualitative Study. BMC Public Health, 12, 743. https://doi.org/10.1186/1471-2458-12-743

[30] Becker, D., Diaz-Olavarrieta, C., Juarez, C., Garcia, S.G., Smith, P.S. and Harper, C.C. (2011) Sociodemographic Factors Associated with Obstacles to Abortion Care: Findings from a Survey of Abortion Patients in Mexico City. Women Health Iss, 21, S16-S20. 
[31] Banerjee, S.K., Andersen, K.L., Buchanan, R.M. and Warvadekar, J. (2012) Woman-Centered Research on Access to Safe Abortion Services and Implications for Behavioral Change Communication Interventions: A Cross-Sectional Study of Women in Bihar and Jharkhand, India. BMC Public Health, 12, 175.

https://doi.org/10.1186/1471-2458-12-175

[32] Dressler, J., Maughn, N., Soon, J.A. and Norman, W.V. (2013) The Perspective of Rural Physicians Providing Abortion in Canada: Qualitative Findings of the BC Abortion Providers Survey (BCAPS). PLoS ONE, 8, e67070.

[33] Norman, W.V., Soon, J.A., Maughn, N. and Dressler, J. (2013) Barriers to Rural Induced Abortion Services in Canada: Findings of the British Columbia Abortion Providers Survey (BCAPS). PLoS ONE, 8, e67023.

[34] Samandari, G., Wolf, M., Basnett, I., Hyman, A. and Andersen, K. (2012) Implementation of Legal Abortion in Nepal: A Model for Rapid Scale-Up of High-Quality Care. Reproductive Health, 9, 1-11. https://doi.org/10.1186/1742-4755-9-7

[35] Rosenthal, D., Rowe, H., Mallett, S., Hardiman, A. and Kirkman, M. (2009) Understanding Women's Experiences of Unplanned Pregnancy and Abortion: University of Melbourne.

[36] Thapa, S., Sharma, S.K. and Khatiwada, N. (2014) Women's Knowledge of Abortion Law and Availability of Services in Nepal. Journal of Biosocial Science, 46, 266-277. https://doi.org/10.1017/S0021932013000461 